\title{
Factors Associated with Satisfaction with a Community Mental Health Service ${ }^{1}$
}

\author{
Kênia Izabel David Silva de Resende ${ }^{2}$, Marina Bandeira ${ }^{3}$, Daniela Carine Ramires de Oliveira ${ }^{3}$ \\ ${ }^{2}$ Centro Universitário de Lavras, Lavras-MG, Brazil \\ ${ }^{3}$ Universidade Federal de São João del-Rei, São João del-Rei-MG, Brazil
}

\begin{abstract}
This study's objective was to simultaneousy assess the factors associated with the satisfaction of 84 patients and 84 family members with treatment and the satisfaction of 67 professionals with the work performed in a mental health service. This is a quantitative cross-sectional study with a correlational design and multivariate data analysis. The participants responded to satisfaction scales and sociodemographic questionnaires. The results indicate that the following variables predicted the level of satisfaction: age at onset of psychiatric disorder; being supported by the professionals; receiving information about treatment; level of education; and years of work in mental health services. The results reveal that establishing a partnership with the families of patients is important to ensuringtheir satisfaction and treatment adherence, while the way the public health system manages the professionals' careers has contributed to their dissatisfaction, requiring urgent reformulation.
\end{abstract}

Keywords: mental health services, community services, public health services, satisfaction

\section{Fatores Associados à Satisfação com um Serviço Comunitário de Saúde Mental}

Resumo: Este estudo teve por objetivo avaliar, simultaneamente, os fatores associados à satisfação de 84 pacientes e de 84 familiares com o tratamento recebido e a satisfação de 67 profissionais com o trabalho realizado em um serviço de saúde mental. Trata-se de uma pesquisa quantitativa, de corte transversal, com delineamento correlacional e análise de dados multivariada. Os participantes responderam questões das Escalas de Satisfação e questionários sociodemográficos. Os resultados apontaram que as variáveis idade de início do transtorno psiquiátrico, receber o apoio dos profissionais, receber informações sobre o tratamento, nível de escolaridade e tempo de trabalho em saúde mental foram preditoras do grau de satisfação. A parceria com as famílias dos pacientes é importante para garantir sua satisfação e adesão ao tratamento. A forma como o sistema público de saúde gerencia a carreira dos profissionais tem contribuído para a sua insatisfação, necessitando de reformulações urgentes.

Palavras-chave: serviços de saúde mental, serviços comunitários, serviços de saúde pública, satisfação

\section{Factores Asociados con la Satisfacción con un Servicio de Salud Mental de la Comunidad}

\begin{abstract}
Resumen: Este estudio evaluó tanto los factores asociados con la satisfacción de 84 pacientes y 84 miembros de la familia con el tratamiento recibido y la satisfacción de 67 profesionales para trabajar en un servicio de salud mental. Se trata de una investigación cuantitativa, de corte transversal, con delineamiento correlacional y análisis de datos multivariada. Los participantes respondieron a las preguntas de las escalas de satisfacción y cuestionarios demográficos. Los resultados mostraron que las variables: edad de inicio del trastorno psiquiátrico, reciben el apoyo de profesionales, reciben información sobre el tratamiento, el nivel de educación y tiempo de trabajo en la salud mental eran predictores de la satisfacción. Los resultados mostraron que la asociación con las familias de los pacientes es importante para asegurar su satisfacción y adherencia al tratamiento y la forma en que el sistema de salud pública gestiona la carrera profesional ha contribuido a su insatisfacción que requiere reformulaciones urgentes.
\end{abstract}

Palabras clave: servicios de salud mental, servicios comunitarios, servicios de salud pública, satisfacción

'Paper derived from the Master's thesis by the first author, under the advice of the second author and co-advised by the third author, defended for the Graduate Program in Psychology at the Universidade Federal de São João del-Rei. Support: Foster Program directed to the Graduated Program at the Universidade Federal de São João del-Rei, Decree/MEC 2.684, from September 25, 2003 (Report No. 006 de 25/02/2013 CONDI-UFSJ).

Correspondence address: Kênia Izabel David Silva de Resende. Centro Universitário de Lavras. Rua Padre Bernardo Kaowner, 15, Centenário. Lavras-MG, Brazil. CEP 37.200-000. E-mail: keniaizabel@unilavras.edu.br
The Psychosocial Care Centers (CAPS), created as a result of the Psychiatric Reform movement, enabled increased participation of patients and their families in the routines of these services (Kantorski, 2012; Kustner, González, \& García, 2002; Silva, Melo, \& Esperidião, 2012). Patients are no longer treated as passive recipients of care; rather, they play a collaborative role, aiming 
at improved services and advocacy for the rights of individuals with psychiatric disorders, preventing the return of older asylum practices. These actions became possible due to organized movements such as patient councils supported by mental health professionals and professional associations (Costa \& Paulon, 2012). Hence, it is essential, in this new context, to take into account the subjective evaluations of patients to measure the quality of care in regard to the structure, processes and outcomes achieved by mental healthcare services and monitor whether the principles of Psychiatric Reform are being implemented (Costa \& Paulon, 2012; McCabe, Saidi, \& Priebe, 2007; Kustner et al., 2002; Silva, 2014).

Among the various subjective measures used to evaluate services from the perspective of patients, satisfaction measures are the ones most frequently used (Ruggeri, 2010). Assessments of services based on satisfaction measures were implemented beginning in the 1960s in European and North American countries (Einsen, 2010). In Brazil, assessments focusing on the satisfaction of patients intensified beginning in the 1990s, due to the expansion of the Brazilian Health Service (SUS) and guidelines recommending the social participation of patients inplanning processes and assessments of health services (Furtado, OnockoCampos, Moreira, \& Trapé, 2013; Kantorski, 2012; Silva et al., 2012). The participation of patients is essential to coping with one of the greatest challenges threatening mental health services: the risk of institutionalization (Costa \& Paulon, 2012). Even though the older lunatic asylums were restructured and replaced by modern substitutive services, such services should be constantly assessed in order to monitor the quality of care provided and prevent the return of asylum and institutionalizing practices (Costa \& Paulon, 2012; Furtado et al., 2013). The assessment of satisfaction, a subjective measure that indicates quality, can contribute to this purpose (Kustner et al., 2002; Ruggeri, 2010).

Since measures of satisfaction have been acknowledged as a proper indicator of quality to assess healthcare services, researchers have developed theoretical models able to explain the bases upon which patients make judgments concerning satisfaction with health services (Ruggeri, 2010; Silva, 2014). Some conceptual models of satisfaction measures were developed and the Theory of Expectations has been the most frequently adopted by studies assessing patient satisfaction (Ruggeri, 2010; Silva, 2014). Satisfaction, according to this theoretical model, is understood from an emotional and cognitive perspective, determined by a comparison between one's subjective expectations at the beginning of treatment and one's concrete experience with the treatment received (Ruggeri, 2010).

Even though the importance of considering the perspective of patients when assessing mental health services has been recognized, as has the fact that a satisfaction measure is an indicator of quality, studies assessing levels of patient satisfaction have been unequally conducted (Bandeira \& Silva, 2012; Perreault, Rousseau, Provencher, Roberts, \& Milton, 2011; Resende, Bandeira, \& Oliveira, 2016; Silva, 2014). Patients compose the most frequently addressed group, at the expense of family members and workers (Leal, Bandeira, \& Azevedo, 2012; Perreault et al., 2011). Additionally, there are few studies including multiple perspectives, that is, simultaneously assessing the perspectives of all those involved: patients, families, and professionals, when assessing the same service (Camilo, Bandeira, Leal, \& Scalon, 2012; Resende et al., 2016; World Health Organization [WHO], 2001). There are also few studies addressing the factors associated with satisfaction with services using multiple regression analysis. In general, these studies are restricted to a descriptive assessment of the level of global satisfaction and its domains (Silva, 2014). Nonetheless, the analysis of factors associated with level of satisfaction is important to clarifying which sociodemographic and clinical variables, as well as living and occupational conditions, exert the greatest influence on the satisfaction of patients and professionals. Knowledge concerning associated factors is important because it provides specific data that can aid in the implementation of changes in the planning and functioning of mental health services (Bandeira, 2014).

Only one study published in an indexed scientific journal to date was found in the Brazilian context. It assessed one mental health service from multiple perspectives: that is, it included the opinions of three different groups (Camilo et al., 2012). The study, however, limited itself to presenting a descriptive assessment of global satisfaction and its domains, without investigating the factors associated with the level of satisfaction of these groups in regard to the service. Additionally, the aforementioned study verified satisfaction with a type I CAPS and no similar assessment was found addressing a type III CAPS. Considering a lack of studies addressing this topic, this study's objective was to simultaneously assess the factors associated with the satisfaction of 84 patients and 84 family members with treatment received and the satisfaction of 67 healthcare workers with the work performed in a mental health care service.

\section{Method}

This study assesses the quality of a mental health service and is considered an outcome evaluation, which in the definition provided by Selltiz, Wrightsman and Cook (1981/1987), verifies the results of a service or treatment program. It is also a cross-sectional study, which is defined as a study in which data is collected at a single point in time, with a correlational design in which the relationships among natural variables are investigated, without manipulating independent variables, as occurs in experimental studies (Selltiz et al., 1981/1987). 


\section{Participants}

This study was conducted in a type III CAPS of a large city situated in the metropolitan region of one of the capitals in the southern region of Brazil. The service has ten beds to serve patients overnight whenever necessary, from a few hours to a maximum of seven days. There is night shift and 24-hour clinical support. Among the service's activities are included artistic workshops and vocational orientation, recreational activities and a council of patients, though not all these activities are regular, as they are subject to the availability of professionals.

A total of 235 people were divided into three different samples: 84 patients, 84 family members, and a third sample composed of 67 mental health workers. Different techniques to select each of the samples were used. The patients were selected through a non-probabilistic method, the accidental subtype, in which the participants are selected according to their presence at a pre-determined time and place (Selltiz et al., 1981/1987), such as days of consultation with the psychiatric physician at CAPS. The sample size was intended to reach a sample power of $90 \%$ so that statistical calculations were performed to determine the appropriate sample size (Snedecor \& Cochran, 1971). The patients whose medical files indicated the diagnostic categories of Schizophrenia and related disorders (F20 to F29) and Affective Disorders (F30 to F39), according to the International Classification of Diseases (ICD-10) (Organização Mundial da Saúde [OMS], 1994), were interviewed. In order to obtain a more homogenous sample and avoid interferences from spurious variables in the interpretation of results, inclusion and exclusion criteria were adopted. Inclusion criteria were: patients 18 years old or older, of either gender, receiving treatment at the CAPS for at least three months, and having a family caregiver. Exclusion criteria were: having psychiatric comorbidities, such as abusive consumption of alcohol or drugs, cognitive deficits, neurological problems, or being unable to understand and answer the questions from the measurement instruments.

The sample of family members was selected by the primary author with the aid of the service's mental health workers. A family caregiver who met the inclusion criteria was selected for each patient. Family caregivers met the following inclusion criteria: being 18 years old or older, of either gender; living in the same home as the patient; being the primary caregiver; and accompanying the patient to the psychiatric consultations. Exclusion criteria were: having difficulty understanding the questions contained in the instrument, or presenting psychiatric disorders.

The mental health service had a staff of 77 professionals and, for this reason, the entire target population was interviewed instead of establishing a sample. All the workers present at the time of data collection and who worked at the service for at least six months were invited to participate in the study. Of the 77 workers, three did not consent to participate, five were on vacation or medical leave, and two did not return questionnaires, resulting in a total of 67 participants.

\section{Instruments}

The short versions of three scales specific to assessing mental health services were used, namely: Satisfaction with Mental Health Services Scale - SATIS-BR. These questionnaires were developed by the Mental Health Division of the World Health Organization and adapted to and validated for the Brazilian context (Bandeira, Mercier, Perreault, Libério, \& Pitta, 2002; Bandeira, Pitta, \& Mercier, 2000; Bandeira \& Silva, 2012).

The short version of the SATIS-BR/Patients presents 12 items divided into three subscales assessing the competence and understanding of the staff regarding the problems presented by the patient; how well the staff welcomes and aids patients; and the service's infrastructure (Bandeira \& Silva, 2012). The short version of SATIS-BR/ Family caregiver contains eight items divided into three subscales assessing the satisfaction of family caregivers in regard to: the outcomes of the patient's treatment; satisfaction in regard to how the staff welcomes patients and competence; and satisfaction in regard to aspects such as privacy and confidentiality of the service during treatment (Bandeira et al., 2002). The short version of the SATIS-BR/Professionals contains 32 items distributed into four subscales assessing the satisfaction of professionals in regard to the following aspects: quality of the care provided to patients; participation in the service's decision-making; work conditions; and the relationship with coworkers and managers. The answers to the three scales are expressed on a five-point Likert scale in which $1=$ very dissatisfied, $2=$ dissatisfied, $3=$ moderately satisfied, $4=$ satisfied, and $5=$ very satisfied (Bandeira et al., 2000).

The scales present appropriate psychometric properties. The computation of Cronbach's alpha to verify internal consistency presented appropriate values for the global scores (SATIS-BR/Patients 0.88; SATIS-BR/ Family caregivers 0.79; SATIS-BR/Professionals 0.89), showing that the scales present good reliability indexes (Bandeira et al., 2000; Bandeira et al., 2002; Bandeira \& Silva, 2012).

In addition to the scales, three different sociodemographic questionnaires were used to assess each of the three samples. The questionnaires were developed and tested in the targetpopulations in order to verify that they were appropriate and easy to understand.

\section{Procedure}

Data collection. Different methods were used to collect data from patients, family caregivers, and professionals. The instruments were applied to patients and family caregivers in the mental health service through individual interviews, during which the researchers read the questions and took notes for the answers. In order to standardize 
data collection, all the interviewers were specifically trained to apply the instruments. The Probing Technique, which consists of asking the respondents to justify each of their answers, was used in interviewing patients and family caregivers. This technique was employed to assess their understanding of the questions asked in the instrument (Guillemin, Bombardier, \& Beaton, 1993). The professionals self-administered the instruments after receiving the necessary explanation to complete them. The researcher remained available to the professionals to clarify potential doubts regarding the questions addressed in the instruments.

Data analysis. Data were analyzed using the Statistical Package for Social Sciences (SPSS), version 20.0. Descriptive statistical analysis was performed, presenting means, standard deviations, and percentages to describe the sociodemographic characteristics of the samples and verify the global scores obtained on the SATIS-BR. To analyze the factors associated with satisfaction with the service, three multiple linear regression models were used, one for the patients, another for the family caregivers, and a third one for the staff. The dependent variable was the degree of satisfaction (measured by the global score of SATIS-BR), while the independent variables were: sociodemographic variables (for the three groups), clinical variables (patients), living conditions (family caregivers), and occupational variables (for the professionals). In order to select the independent variables that would be included in the regression models, a univariate analysis was first performed using Student's t-test and Pearson's correlation test. The variables that were significant in the univariate analyses $(p \leq 0.05)$ were selected, as well as the variables with a $p \leq 0.25$. According to Hosmer and Lemeshow (2000), the latter should be included in the regression model, as they may be found significant in the multivariate analyzes. The variables were selected for the regression models according to the Step wise technique.

\section{Ethical Considerations}

Ethical issues were taken into account during the entire study. The project was submitted to and approved by the Institutional Review Board at the Universidade Federal de São João del-Rei where the study was conducted (Report 023/2013). The coordinator of the service was contacted and received clarification regarding the study's objectives and procedures, authorizing its implementation. The patients, family caregivers and workers also received clarification regarding the study's objectives, were ensured confidentiality, were informed of the voluntary nature of their participation, as well as that there were no risks or damage that would result, or the need for further information, in accordance with the guidelines provided by Resolution 466, from December $12^{\text {th }} 2012$, Conselho Nacional de Saúde (CNS). Data collection was initiated only after the participants signed free and informed consent forms.

\section{Results}

\section{Description of Samples}

The sociodemographic characteristics of the patient sample reveal the following composition: most were women (51.2\%); aged 43 years old on average; single (54.7\%); unemployed $(86.9 \%)$; with incomplete primary/middle school (50\%); with income (63.1\%) of a minimum wage, on average $(50.9 \%)$, provided by Social Security $(34.0 \%)$.

In regard to the patients' clinical characteristics: the average age at the onset of the psychiatric disorder was 26.55 years old, while patients had received treatment for an average of 10.23 years. The diagnostic categories most frequently reported were those from the Schizophrenia group, Schizotypal Disorders, and Delusional Disorders (69\%); most did not present psychiatric comorbidities $(83.3 \%)$ or physical diseases $(64.3 \%)$. Most had not experienced psychiatric crises in the last year $(53.6 \%)$ and were never hospitalized in psychiatric hospitals (73.8\%). All the patients received psychiatric care and medications free of charge, while some also received psychological care $(39.3 \%)$. Most used oral medication $(72.6 \%)$ and took self-administered medication (66.7\%).

The sample of family caregivers presented the following sociodemographic characteristics: average age of 51 years old, with a range from 22 to 84 years old; most were women (73.8\%); were married (57.1\%); with children $(91.7 \%)$; were the mothers of the patients (41.7\%); had incomplete primary/middle school (46.4\%); had a paid job at the time of data collection $(56 \%)$, which was their primary source of income (54.7\%); and had a monthly income less than two times the minimum wage $(35.9 \%)$.

In regard to the living conditions of family caregivers, most reported being responsible for the care provided to the patient for more than 11 years $(59.5 \%)$. Most family caregivers reported some physical disease $(60.7 \%)$; had already felt ill due to their caregiver role (65.5\%); had received information regarding the patient's situation $(65.5 \%)$; and such information was provided by the responsible technical staff $(92.7 \%)$. Most caregivers reported having the support of the mental health service whenever necessary $(92.7 \%)$.

The sociodemographic characteristics of the professionals show: an average age of 41 years old, while most were women $(70.1 \%)$ and single $(50.7 \%)$. In regard to the occupational characteristics, the most frequently reported professions were nursing technicians (41.8\%), psychiatrists (16.4\%) and nurses (11.9\%). Most professionals had worked from one to five years in the mental health service $(52.2 \%)$; the predominant workload was 30 hours a week (67.2\%); and most had a second job (68.7\%). Those with a second job considered the work performed in the mental health service to be more strenuous $(58.7 \%)$, having already considered the possibility of changing jobs (47.8\%). 


\section{Factors Associated with the Global Satisfaction of the Patients}

The sociodemographic and clinical variables preselected according to the univariate analyses and included in the regression model were: patient's age; age at the onset of the psychiatric disorder; duration of the last hospitalization; type of therapeutic intervention; patient's gender; reason why the patient was referred to a psychiatric hospital; independence to take one's own medication; having an income; having been hospitalized prior to the mental health service; type of medication used; having leisure activities; and undergoing treatment for physical diseases.

Table 1 presents the results concerning the regression analysis concerning the factors associated with the satisfaction of patients with the mental health service. The results indicate that the variable "age at the onset of the psychiatric disorder" was the only one predicting the global satisfaction of patients with the service $(D W=1.91 ; F=6.449, p=0.013)$. The patients were more satisfied with the service when the psychiatric disorder emerged later in their lives.

Table 1

Multiple linear regression analysis of sociodemographic and clinical variables associated with the global satisfaction of patients with a mental health service

\begin{tabular}{|c|c|c|c|c|c|}
\hline $\begin{array}{l}\text { Associated } \\
\text { variable }\end{array}$ & Beta & $\mathrm{SE}^{*}$ & $t$ & $p$ & \\
\hline Constant & 3.310 & 0.162 & 20.463 & 0.000 & $F=6.449$ \\
\hline $\begin{array}{l}\text { Age at the onset of } \\
\text { psychiatric disorder }\end{array}$ & 0.015 & 0.006 & 2.540 & 0.013 & $\begin{array}{l}(p=0.013) \\
D W=1.91\end{array}$ \\
\hline
\end{tabular}

Note. ${ }^{*} \mathrm{SE}=$ Standard Error

\section{Factors Associated with the Global Satisfaction of the Family Caregivers}

The sociodemographic variables and living conditions pre-selected according to univariate analyses were: gender of the family caregiver; having received information regarding the patient's psychiatric disorder; having been supported by the professionals who provide care to the patient; having a formal or informal job; taking care of other family members in addition to the patient; having health problems; having become sick due to the caregiver role; having a leisure activity; having an income; number of people in the family under the care of the family caregiver; number of the caregiver's health problems; and number of problem behaviors presented by the patient.

Table 2 presents the factors associated with the satisfaction of family caregivers with the mental health service. The results reveal that the variables "feeling supported by the professionals who provide care to the patient" and "receiving information regarding the patient's psychiatric disorder" were predictors of family caregiver satisfaction with the service $(D W=1.912$; $F=12.284 ; p=0.00)$. The regression line coefficients indicate that the family caregivers were more satisfied with the mental health service when they felt supported by the workers responsible for care delivery, followed by when they received information regarding the patient's psychiatric disorder.

Table 2

Multiple linear regression analysis of sociodemographic variables and living conditions associated with the global satisfaction of family caregivers with a mental health service

\begin{tabular}{|c|c|c|c|c|c|}
\hline Associated variables & Beta & $\mathrm{SE}^{*}$ & $t$ & $p$ & \\
\hline Constant & 3.602 & 0.168 & 21.462 & 0.00 & \\
\hline $\begin{array}{l}\text { 1. Feels supported by } \\
\text { the professionals who } \\
\text { provide care to the } \\
\text { patient } \\
\text { 2. Receives sufficient } \\
\text { information regarding } \\
\text { the patient's } \\
\text { psychiatric disorder }\end{array}$ & 0.344 & 0.132 & 2.612 & 0.01 & $\begin{array}{c}F=12.284 \\
(p=0.00) \\
D W=1.912\end{array}$ \\
\hline
\end{tabular}

Note. ${ }^{*} \mathrm{SE}=$ Standard Error

\section{Factors Associated with the Global Satisfaction of the Professionals}

The sociodemographic and occupational variables preselected according to the univariate analyses were: distance from the service and the professional's residence; believing that distance affects one's work; years of schooling; years working in a mental health service; living with a partner; considering changing jobs; age; and weekly workload.

Table 3 presents the factors associated with the satisfaction of professionals in regard to the mental health service. The results show that the variables "years of schooling" and "years of work" were the only predictors of satisfaction with the service among the professionals $(D W=$ $1.62 ; F=4.420, p=0.00)$. The regression line coefficients indicate that the professionals were more satisfied with the service when they presented a lower level of education, followed by when they had worked fewer years in a mental health service.

Table 3

Multiple linear regression analysis of sociodemographic and occupational variables associated with the global satisfaction of professionals with a mental health service

\begin{tabular}{cccccc}
\hline Variables & Beta & SE* $^{*}$ & $t$ & $P$ & \\
\hline Constant & 3.940 & 0.295 & 13.376 & 0.00 & $F=4.42$ \\
Years of schooling & -0.047 & 0.020 & -2.370 & 0.02 & $(p=0.00)$ \\
Years of work & -0.015 & 0.009 & -1.721 & 0.09 & $D W=1.62$ \\
\hline
\end{tabular}

Note. $* \mathrm{SE}=$ Standard Error

\section{Discussion}

This study's results present the factors associated with satisfaction with the mental health service of patients, family caregivers, and workers. The late onset of the psychiatric 
disorder was the only predictor of the patients' satisfaction with the service. Comparison among studies was not possible, as no other studies performing multivariate analyses or that had identified this same predictor of satisfaction were found. A potential explanation is that psychiatric disorders negatively affect the lives of patients. When the onset of psychopathological conditions occur in the first years of adult life, a more severe prognosis is usually established, preventing individuals from having a job or engaging in educational activities or social relationships (WHO, 2001), which may decrease their satisfaction with treatment and life, in general (Ruggeri, 2010; WHO, 2001). This piece of information leads to reflection on the importance of early diagnosis and intervention for such conditions, in addition to the importance of establishing collaboration among the various devices available in the public health network. The treatment of psychiatric disorders in the primary health care enables easy and fast access to services for a greater number of people so that more appropriate interventions and devices are implemented and provided. Nonetheless, for this cooperation to occur, CAPS needs to work together with other devices available in the health network, bringing together topics that are related to both general health and mental health, creating an interdisciplinary space to discuss knowledge and practices. Matrix support, for instance, is a strategy to implement proper public health work and promote mental health actions in the primary healthcare network, contributing to the early identification and treatment of psychiatric conditions. Given the relevance of such results, it is important to consider to what extent general health services and those providing mental health care have been able to cooperate and to verify whether the proposals from the Psychiatric Reform have actually been implemented.

The multivariate analyses show that family caregivers who had the support of health workers and also received more information on the patients' clinical conditions and treatments were more satisfied with the mental health service. The studies conducted by Gigantesco, Picardi, Chiaia and Morosini (2002) and by Perreault et al. (2011) addressing the family members of psychiatric patients corroborate these findings. These results show the importance of including family in the treatment of patients so that the health staff needs to clearly understand the adjuvant and collaborative role of family caregivers and properly integrate them into treatment. Supporting and providing information to family caregivers is a way to bring them closer and prepare them to deal more effectively with the problems presented by patients. Most patients and families using mental health services face poor living conditions and they sometimes have only a basic repertoire of skills to deal with problems in their daily routine. Providing information from a psycho educational perspective, promotes greater involvement and is a way to welcome, help and encourage the family members to collaborate with the patients' treatment. The collaboration of families is very advantageous and strengthens advocacy of the rights of people with psychiatric disorders, encourages treatment adherence, contributes to the better management of overload experienced by family caregivers and improves the relationship between family caregivers and patients (Bandeira, 2014; Costa \& Paulon, 2012; Ruggeri, 2010).

The professionals with more years of education and more years of work in mental health presented the lowest levels of satisfaction. This result corroborates the study conducted by De Marco, Cítero, Moraes and Nogueira-Martins (2008), by Pelisoli, Moreira and Kristensen (2007), and by Rebouças, Abelha, Legay and Lovisi (2008). Management turnover is common in public services given the very nature of public institutions, where managers are usually changed every four years. Management turnover may harm the development of long-term projects, as priorities change with every new management team and many projects are not concluded or even initiated. In the study conducted by Pelisoli et al. (2007), the professionals who had already experienced such a situation, that is, had more years of work in mental health, were more dissatisfied with their professional lives. The importance of measuring and reflecting on the consequences of work dissatisfaction among those in mental health services is that, compared to other health fields, mental health services depend much more on human resources than on technological equipment (Thornicroft \& Tansella, 2010). The therapeutic relationships and personal skills of professionals are essential and influence patients' adherence and decisions to continue treatment, contributing to improve outcomes (Rebouças et al., 2008). Note that the technical staff is not a fixed resource, as it is subject to constant attrition given the very nature of the work, which involves intense and frequent contact with individuals with severe mental disorders (Thornicroft \& Tansella, 2010). Therefore, it is imperative to consider how the public system manages mental health workers. A lack of a career plan and of material and motivational incentives capable of keeping professionals in their job positions, in addition to poor work conditions, contribute to the dissatisfaction of these workers, which in turn harms their quality of life and the quality of care delivery.

These results reveal the aspects that need to be considered to achieve improved quality of mental health services from the perspective of satisfaction of patients, family caregivers, and workers. The suggestions presented are based on the data collected in this study and aim to contribute to the planning and management of mental health services to achieve improved results in the care provided to psychiatric patients and families, as well as to the technical staff. These suggestions can also aid mental health services, especially CAPS III, which are responsible for providing care to patients in a time of vulnerability, such as when facing an acute crisis, to comply with the principles recommended by the Psychiatric Reform proposal.

This study presents some limitations. The samples were not randomly collected from the target population, which hinders the generalization of results (Selltiz et al., 1981/1987). Another limitation is that this is a correlational study and this type of design does not allow for the establishment of causal relationships among the variables analyzed here 
(Campbell \& Stanley, 1979). Additionally, due to a lack of Brazilian studies addressing CAPS III, we were not able to compare the results with those reported by other studies addressing this same type of service, especially because a multiple perspective was adopted in this study; that is, three different groups from the same service were simultaneously addressed. Further studies should collect similar information from large services, such as type III CAPS located in other Brazilian regions, to deepen knowledge concerning the factors associated with satisfaction with this type of service. Qualitative studies adopting multiple perspectives should also be conducted in order to complement knowledge concerning the evaluation of the quality of care provided by mental health care services, taking into account the perspectives of workers and those individuals using these services.

\section{References}

Bandeira, M. (2014). Princípios norteadores para a avaliação de serviços de saúde mental [Guiding principles for the evaluation of mental health services]. In M. Bandeira, L. A. Lima, \& S. Barroso (Orgs.), Avaliação de serviços de saúde mental: Princípios metodológicos, indicadores de qualidade e instrumentos de medida [Mental health services reviewed methodological principles, quality indicators and measurement instruments] (pp. 19-54). Petrópolis, RJ: Vozes.

Bandeira, M., Mercier, C., Perreault, M., Libério, M. M. A., \& Pitta, A. M. F. (2002). Escala de avaliação da satisfação dos familiares com os serviços de saúde mental: SATISBR [The Brazilian mental health services' family satisfaction scale: SATIS-BR]. Jornal Brasileiro de Psiquiatria, 51(3), 153-166.

Bandeira, M., \& Silva, M. A. (2012). Escala de satisfação dos pacientes com os serviços de saúde mental (SATISBR): Estudo de validação [Patients' satisfaction with mental health services scale (SATIS-BR): validation study]. Jornal Brasileiro de Psiquiatria, 61(3), 124-32. doi:10.1590/S0047-20852012000300002

Bandeira, M., Silva, M. A., Camilo, C. A., \& Felício, C. M. (2011). Satisfação de familiares de pacientes psiquiátricos com os serviços de saúde mental e seus fatores associados [Family satisfaction in mental health services and associated factors] Jornal Brasileiro de Psiquiatria, 60(4), 284-293. doi:10.1590/S004720852011000400009

Camilo, C. A., Bandeira, M., Leal, R. M. A. C., \& Scalon, J. D. (2012). Avaliação da satisfação e sobrecarga em um serviço de saúde mental [Satisfaction and burden evaluation in a mental health service]. Cadernos de Saúde Coletiva, 20(1), 82-92. Retrieved from http://iesc.ufrj.br/ cadernos/images/csc/2012_1/artigos/CSC_v20n1_8292.pdf
Campbell, D. T., \& Stanley, J. C. (1979). Delineamentos experimentais e quase experimentais de pesquisa [Experimental designs and quasi-experimental research] (R. A. T. Dio, Trans.). São Paulo, SP: Edusp.

Costa, D. F. C., \& Paulon, S. M. (2012). Participação social e protagonismo em saúde mental: A insurgência de um coletivo [Social participation and protagonism in mental health: The rising of a collective]. Saúde em Debate, 36(95), 572-582. doi:10.1590/S010311042012000400009

De Marco, P. F., Cítero, V. A., Moraes, E., \& NogueiraMartins L. A. (2008). O impacto do trabalho em saúde mental: Transtornos psiquiátricos menores, qualidade de vida e satisfação profissional [Job impact on mental health workers: Minor psychiatric disorders, quality of life and job satisfaction]. Jornal Brasileiro de Psiquiatria, 57(3), 178-183. doi:10.1590/S0047-20852008000300004

Einsen, S. V. (2010). Patient satisfaction and perceptions care. In W. W. IsHak, T. Burt, \& L. I. Sederer (Eds.), Outcomes measurement in psychiatry: A critical review (pp. 303320). Washington, DC: American Psychiatric Publishing.

Furtado, J. P., Onocko-Campos, R. T., Moreira, M. I. B., \& Trapé, T. L. (2013). A elaboração participativa de indicadores para a avaliação em saúde mental [Participatory development of indicators for assessing mental health]. Cadernos de Saúde Pública, 29(1), 102110. doi: 10.1590/S0102-311X2013000100012

Gigantesco, A., Picardi, A., Chiaia, E., Balbi, A., \& Morosini, P. (2002). Patients' and relatives' satisfaction with psychiatric services in a large catchment area in Rome. European Psychiatry, 17(3), 139-147. doi. org/10.1016/S0924-9338(02)00643

Guillemin, F., Bombardier, C., \& Beaton, D. (1993). Crosscultural adaptation of health-related quality of life measures: Literature review and proposed guidelines. Journal of Clinical Epidemiology, 46(12), 1417-1432. doi:10.1016/0895-4356(93)90142-N

Hosmer, D. W., \& Lemeshow, S. (2000). Applied logistic regression (2nd ed.). New York, NY: Wiley.

Kantorski, L. P. (2012). Os desafios da avaliação no campo da saúde mental [The assessment of the challenges in the mental health field]. Revista Eletrônica de Enfermagem, 14(1), 10-11. doi:10.5216/ree.v14i1.27472

Leal, R. M.A.C., Bandeira, M. B., \&Azevedo, K. R. N.(2012). Avaliação da qualidade de um serviço de saúde mental na perspectiva do trabalhador: Satisfação, sobrecarga e condições de trabalho dos profissionais [Evaluation of a mental health service quality in the perspective of their professionals: satisfaction, burden and work conditions]. Psicologia: Teoria e Prática, 14(1), 15-25. Retrieved from http://pepsic.bvsalud.org/scielo.php?script=sci arttext\&pid=S1516-36872012000100002 
McCabe, R., Saidi, M., \&Priebe, S. (2007). Patient-reported outcomes in schizophrenia. The British Journal of Psychiatry Supplement, (50), s21-28.doi:10.1192/bjp.191.50.s21

Moreno Kustner, B., Torres González, F., \& Godoy García, J. F. (2002). Evaluación de los servicios de salud mental en el ámbito de La atención comunitaria. Actas Españolas de Psiquiatría, 30(4), 253-258.

Organização Mundial da Saúde. (1994). CID-10: Classificação estatística internacional de doenças e problemas relacionados à saúde (10th ed.). São Paulo, SP: Edusp.

Pelisoli, C., Moreira, A. K., \& Kristensen, C. H. (2007). Avaliação da satisfação e do impacto da sobrecarga de trabalho em profissionais de saúde mental [Assessment of satisfaction and impact of work overload among mental health professionals]. Mental,5(9), 63-78.Retrieved from http://pepsic.bvsalud.org/pdf/mental/v5n9/v5n9a05.pdf

Perreault, M., Rousseau, M., Provencher, H., Roberts, S., \& Milton, D. (2011). Predictors of caregiver satisfaction with mental health services. Community Mental Health Journal, 48(2), 232-237. doi:10.1007/s10597-011-9403-z

Rebouças, D., Legay, L. F., \& Abelha, L. (2008). Satisfação com o trabalho e impacto causado nos profissionais de serviço de saúde mental [Job satisfaction and work impact among providers of a mental health service]. Revista de Saúde Pública, 41(2), 244-250. doi:10.1590/ S0034-89102007000200011

Resende, K. I. D. S., Bandeira, M., \& Oliveira, D. C. R. (2016). Assessment of patient, family and staff satisfaction in a mental health service. Paidéia (Ribeirão Preto), 26(64), 245-253. doi:10.1590/1982-43272664201612

Ruggeri, M. (2010). Satisfaction with psychiatric services. In G. Thornicroft \& M. Tansella (Eds.), Mental health outcome measures (pp. 99-115). London, United Kingdom: Royal College of Psychiatrists.

Selltiz, C., Wrightsman, L. S., \& Cook, S. W. (1987) Métodos de pesquisa nas relações sociais [Research methods on social relationships](D. M. Leite, Trad.).São Paulo, SP: Edusp.(Original publicado em 1981).

Silva, M. (2014). Satisfação dos usuários com os serviços de saúde mental [User satisfaction with mental health services]. In M. Bandeira, L. A. Lima, \& S. Barroso (Orgs.), Avaliação de serviços de saúde mental: Princípios metodológicos, indicadores de qualidade e instrumentos de medida [Mental health services reviewed methodological principles, quality indicators and measurement instruments] (pp. 55-86). Petrópolis, RJ: Vozes.

Silva, N. S., Melo, J. M., \& Esperidião, E. (2012). Avaliação dos serviços de assistência em saúde mental brasileiros: Revisão integrativa da literatura [Assessment of mental health services in Brazil: An integrative literature review]. REME Revista Mineira de Enfermagem, 16(2), 280-288. doi:S1415-27622012000200018
Snedecor, G. W., \& Cochran, W. G. (1971). Métodos estatísticos [Statistical methods] (J. A. Reinosa Fuller, Trans.). São Paulo, SP: Compañia Editorial Continental.

Thornicroft, G., \& Tansella, M. (2010). Boas práticas em saúde mental comunitária (M. T. Muramoto, Trad.). Barueri, SP: Manole.

World Health Organization. (2001). The world health report: Mental health: New understanding, new hope. Geneva, Switzerland: WHO.

Kênia Izabel David Silva de Resende is a Professor of the Psychology of the Centro Universitário de Lavras, LavrasMG, Brazil.

Marina Bandeira is a Professor of the Programa de PósGraduação em Psicologia at the Universidade Federal de São João del-Rei, São João del-Rei-MG, Brazil.

Daniela Carine Ramires de Oliveira is a Professor of the Department of Mathematics and Statistics at the Universidade Federal de São João del-Rei, São João del-Rei-MG, Brazil.

\section{Authors' Contribution:}

All authors made substantial contributions to the conception and design of this study, to data analysis and interpretation, and to the manuscript revision and approval of the final version. All the authors assume public responsability for content of the manuscript.

Received: Nov. 18, 2015

1st Revision: Sep. 14, 2016

Approved: Jan. 24, 2017

How to cite this article:

Resende, K. I. D. S., Bandeira, M., \& Oliveira, D. C. R. (2018). Factors associated with satisfaction with a community mental health service. Paidéia (Ribeirão Preto), 28, e2831. doi: http://dx.doi.org/10.1590/1982-4327e2831 